\title{
The experiences of pregnant women at an advanced maternal age: an integrative review*
}

\author{
As experiências das mulheres na gestação em idade materna avançada: revisão integrativa \\ Las experiencias de las mujeres en la gestión en edad materna avanzada: revisión integradora
}

Juliane Dias Aldrighi ${ }^{1}$, Marilene Loewen Wall², Silvana Regina Rossi Kissula Souza ${ }^{2}$, Franciane Zabloski Vieira Cancela ${ }^{3}$

How to cite this article:

Aldrighi JD, Wall ML, Souza SRRK, Cancela FZV. The experiences of pregnant women at an advanced maternal age: an integrative review. Rev Esc Enferm USP. 2016;50(3):509-518. DOI: http://dx.doi.org/10.1590/S0080-623420160000400019

* Extracted from the dissertation project "A vivência da mulher na gestação em idade materna avançada”, Programa de Pós-Graduação em Enfermagem, Universidade Federal do Paraná, 2015.

${ }^{1}$ Universidade Federal do Paraná, Programa de Pós-Graduação em Enfermagem, Curitiba, PR, Brazil.

${ }^{2}$ Universidade Federal do Paraná, Departamento de Enfermagem, Área Materno-Infantil, Curitiba, PR, Brazil.

${ }^{3}$ Universidade Federal do Paraná, Curso de Graduação em Enfermagem, Curitiba, PR, Brazil.

\begin{abstract}
Objective: To identify in the literature how the experiences of women age 35 or above are described in terms of pregnancy. Method: Integrative review based on MEDLINE/ PubMed, CINAHL, LILACS, and SciELO databases, with no time period constraint. Results: Eighteen studies that dealt with the experiences of pregnant women at an advanced maternal age were selected and analyzed. The studies evidenced four theme categories: the search for information, which pointed to a deficit of information supplied by health care professionals; perceiving the risks, which pointed to women's concerns about their own health and their children's; the ideal moment for motherhood, with different reasons for postponing it; and adjusting to a new routine, showing a concern regarding changes in daily life. Conclusion: From the results, it was possible to understand that other factors, in addition to those that include risks, are present in the experiences of older pregnant women and point to a need to involve such aspects in nursing care to create comprehensive strategies that are aligned with these women's needs.
\end{abstract}

\section{DESCRIPTORS}

Maternal Age; Pregnancy; Nursing Care; Obstetric Nursing; Review.
Corresponding author:

Juliane Dias Aldrighi

Av. Lothário Meissner, 632

Bloco Didático II - Jardim Botânico

CEP 80210-170 - Curitiba, PR, Brazil

juliane.aldrighi@gmail.com
Received: 09/10/2015

Approved: 05/05/2016 


\section{INTRODUCTION}

Currently, postponing motherhood can be considered a worldwide phenomenon: over the last the 30 years, although birth rates have been decreasing, the average mother's age has been gradually increasing ${ }^{(1-2)}$. Numerous factors contribute to this scenario, such as women's stronger presence in the job market, an increase in education and career opportunities for women, and the development of reproductive medicine with regards to family planning and contraceptive methods $s^{(3-4)}$.

Maternal age is considered a risk factor for pregnancy. For Brazil's Ministry of Health, pregnancy among women aged 35 and above is considered late, and it is more prone to complications, which makes it high-risk pregnancy ${ }^{(5)}$.

Although there are advantages related to the decision to have a late pregnancy, this is still associated with adverse obstetric events. In comparison with younger women, studies have shown that among those 35 and above, there are more miscarriages and abortions, and a higher risk for perinatal mortality, ectopic pregnancy, low vitality of newborns, low weight at birth, preterm birth, and fetuses who are small for their gestational age ${ }^{(6-11)}$.

Studies, however, highlight that maternal age alone cannot be a risk factor. Control during the prenatal period, adequate care during childbirth, and childbirth itself make maternal and perinatal prognoses similar to those of younger pregnant women, and positive results are expected from these pregnancies ${ }^{(5,10,12)}$.

The risk perspective, which is based on the biomedical model that still prevails in the health care context, is certainly relevant to prevent and control illnesses; however, this approach falls short, at times, in dealing with the complex scenario of the reproductive phenomenon in advanced age. Gaps in the social, psychological, and cultural scope of health can become obstacles for the development of a healthy pregnancy. The authors consider that pregnancy is a period of various meanings for women, which, in turn, influence their health in such a way that it is necessary to learn about and consider women's experiences and visions regarding their late pregnancy and what they judge relevant for their own and their children's health.

When considering the phenomenon over the last few decades, the authors were concerned with the promotion of health among women in late pregnancy. Because this is a vulnerable population group, these women need individual care that is based on the humanization of health care offered to women.

The studies that deal with advanced maternal age have focused primarily on the relation between the risks and adverse results associated with age $\mathrm{e}^{(1,13-14)}$. There are few studies that highlight the experiences of older pregnant women.

Therefore, the goal of this study is to identify in the literature how the experiences of women age 35 or above are described in terms of pregnancy. Consequently, the knowledge on this issue will be extended and supply resources to enhance the health care that is provided.

\section{METHOD}

This study is an integrative review of the literature on pregnancy in advanced age. The purpose of this type of study is to seek, critically assess, and summarize the available evidence concerning the researched theme. Although it is more comprehensive than other types of review, an integrative review consists of a research method that also demands methodological strictness in all its developmental stages $^{(15)}$. It is an excellent method for nursing, as it allows for building well-founded, uniform knowledge because it provides resources that support decision making and improves nurses' clinical practices ${ }^{(15-16)}$.

In general, an integrative review goes through six different stages ${ }^{(15)}$. The first one is to identify the subject and choose the research question: What is being investigated and published on the experiences of women who get pregnant at a late age? In the second stage, criteria are established to include and exclude studies. The inclusion criteria are as follows: publications that have an abstract; are available on-line in full, with free access; in portuguese, english, or spanish; and whose study object consists of the experiences of women who got pregnant at age 35 or above. The exclusion criteria were as follows: review studies, editorials, opinions/commentaries, and studies whose focus was solely clinical problems. No time frame was used to select the studies, as it was of paramount importance to explore all the possible knowledge published to date.

Searches were conducted in MEDLINE/PubMed, CINAHL, LILACS, and SciELO databases in May 2015. Some of the terms used were "advanced maternal age/advanced reproductive age/delayed motherhood/late childbearing," and associated terms that pointed to the pregnant women's experience such as "perception/life experience/ perspective." The flow diagram (Figure 1) shows the path used to select the publications.
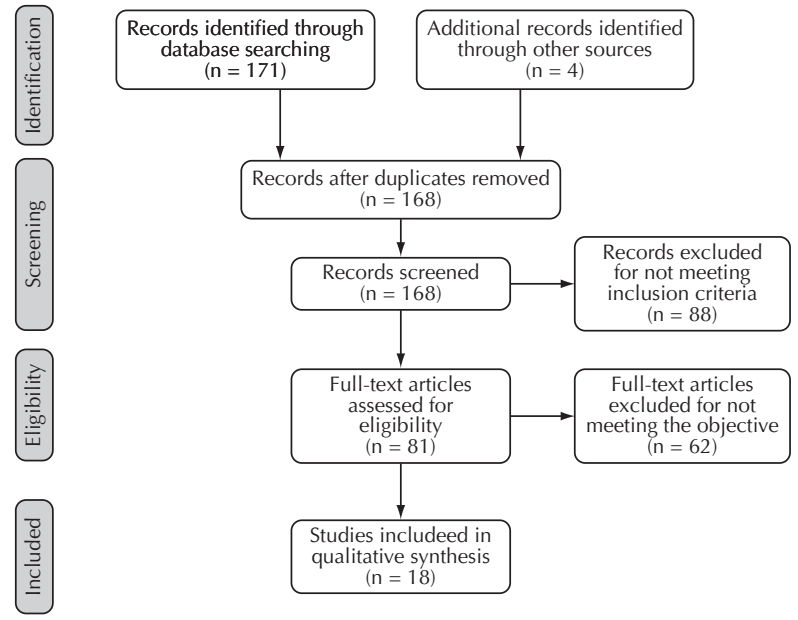

Figure 1 - Flow diagram of publication selection for the integrative review, based on the PRISMA model ${ }^{(17)}$ - Curitiba, Paraná, Brazil, 2015.

The third stage consisted of defining the information to be extracted by means of creating an instrument that contained the following: title, country and year of publication, 
objective, theoretical outline and reference, participants, and main results found by the study.

The fourth stage consisted of filling out and assessing the instrument with the data found in the selected publications. Based on the reading and critical analysis done by two researchers, four categories were created. The fifth stage was discussing and interpreting the results obtained, and the sixth stage was the presentation of the evidence found.

\section{RESULTS}

Eighteen studies were selected and analyzed. Fifteen of them are international scientific articles from the United States (3), Australia (3), the United Kingdom (3), Japan (2), Canada (2), and Taiwan (2). Of the three Brazilian studies found, there was one scientific article and two master's theses. All of the studies in this review were authored by at least one nurse. The years of publication ranged from 1996 to 2015 , and the year with the highest number of studies was 2014 (four articles).

After reading the studies, some common themes emerged and were organized into four categories: the search for information, perceiving the risks, the ideal moment for motherhood, and adjusting to a new routine.

\section{THE SEARCH FOR INFORMATION}

Subjects on information were described in eight studies $^{(18-24)}$, indicating that there is a lack of information on pregnancy and prenatal risk $^{(18-20,23,25)}$, on care for the baby after birth ${ }^{(21,24)}$ and on pregnancy associated with perimenopause ${ }^{(22)}$. As far as older women are concerned, health care professionals focus more on clinical aspects and risks $^{(18,20,23,26-27)}$ associated with pregnancy at a late age and end up leaving subjects that are also considered important for prenatal care into a second plan.

This informational deficit is compensated for by independent searches for information on the Internet, and information from family members and friends ${ }^{(18,20,22-24)}$. One $\operatorname{article}^{(18)}$ said that even though there was little or no information given by professionals, the women who received that information were guided mostly by nurses or obstetric nurses.

The studies depicted the relationship between professionals and older pregnant women as authoritarian and disciplinary ${ }^{(27)}$, embedded with judgments concerning pregnant women's age ${ }^{(18,20,23)}$, and blaming the women for possible health problems their children may have ${ }^{(18-20,23,27)}$.

\section{Perceiving the RISKS}

Fourteen studies showed women's concerns about the risk that their babies would be born with some health problem associated with their maternal age $\mathrm{e}^{(18-21,23,25-26,28-33)}$ and concerns for their own health during pregnancy at an advanced age $\mathrm{e}^{(18-23,25-26,30,33-34)}$.

Some concerns about their own health and maintaining a healthy pregnancy were observed, such as controlling blood pressure ${ }^{(26)}$ and diabetes ${ }^{(23)}$, good nutrition ${ }^{(23,26)}$, and physical exercise ${ }^{(20,22-23,26)}$.

\section{IDEAL MOMENT FOR MOTHERHOOD}

The themes that pertain to this category include the aspects that had led to postponing pregnancy, such as choosing the right partner to have a family with ${ }^{(23,25,32,34-35)}$, the search for financial stability ${ }^{(19,25,27,32-35)}$, and the maturity to conceive a child ${ }^{(19,23,26-27,32-35)}$.

Women considered themselves more emotionally prepared $^{(34)}$, more patient ${ }^{(26)}$, and prouder ${ }^{(29,32)}$ for getting pregnant after the age of 35 , considering it the ideal time for pregnancy. Therefore, they felt fulfilled in their role of mother ${ }^{(20-21,24,26,28-29,31,34)}$ and stated that this was one of the best events of their lives ${ }^{(20)}$, in addition to being a miracle to conceive at that age ${ }^{(21,30)}$.

Whereas they felt more emotionally prepared, some women went through situations that destabilized them and felt uncomfortable in face of society for the fact that they got pregnant after the age of 35 and felt discriminated against for that reason ${ }^{(25,27,34-35)}$.

\section{Adjusting to the NeW ROUTINE}

In this category some studies were included that showed women's difficulty in resuming their daily tasks ${ }^{(26,34)}$, adjusting to the new life routine ${ }^{(19,21,26,29-32)}$, and concern about the impact of the baby's birth on their return to work $^{(19,21,24,26,28,30-31)}$.

Chart 1 shows the studies that were part of the analysis that built the integrative review.

Chart 1 - Studies included in the Integrative Review - Curitiba, Paraná, Brazil, 2015.

\begin{tabular}{|c|c|c|c|c|c|}
\hline Title & $\begin{array}{c}\text { Country/ } \\
\text { Year of } \\
\text { Publication }\end{array}$ & Objective & $\begin{array}{c}\text { Theoretical } \\
\text { Outline/ } \\
\text { Framework }\end{array}$ & Participants & Main Results \\
\hline $\begin{array}{c}\text { Midwifery care } \\
\text { in the UK for } \\
\text { older mothers }\end{array}$ & $\begin{array}{c}\text { To understand the experience } \\
\text { of having a child at } \\
\text { Kingdom } \\
\text { advanced maternal age; to } \\
\text { investigate the care offered } \\
\text { by health care professionals } \\
\text { during pregnancy and the } \\
\text { postnatal period from the } \\
\text { perspective of older women }\end{array}$ & $\begin{array}{c}\text { Qualitative/ } \\
\text { Quantitative/ } \\
\text { Cross-sec- } \\
\text { tional study }\end{array}$ & $\begin{array}{c}397 \text { women who } \\
\text { had children } \\
\text { when above } 35 \\
\text { years of age }\end{array}$ & $\begin{array}{c}\text { Many women said they had received } \\
\text { good care by obstetric nursing } \\
\text { professionals; others, however, } \\
\text { felt their need for care had not } \\
\text { been met or the support offered to } \\
\text { them had not been adequate. }\end{array}$ \\
\hline
\end{tabular}


...continuation

\begin{tabular}{|c|c|c|c|c|c|}
\hline Title & $\begin{array}{l}\text { Country/ } \\
\text { Year of } \\
\text { Publication }\end{array}$ & Objective & $\begin{array}{l}\text { Theoretical } \\
\text { Outline/ } \\
\text { Framework }\end{array}$ & Participants & Main Results \\
\hline $\begin{array}{c}\text { Postponing } \\
\text { motherhood: } \\
\text { becoming a } \\
\text { mother above } 35 \\
\text { years of age }^{(19)}\end{array}$ & $\begin{array}{l}\text { Brazil } \\
1999\end{array}$ & $\begin{array}{l}\text { To analyze the perceptions } \\
\text { of women who postponed } \\
\text { maternity for later than age } \\
35 \text { in terms of their family/ } \\
\text { marital relationships, work, } \\
\text { pregnancy, and motherhood }\end{array}$ & $\begin{array}{l}\text { Qualitative/ } \\
\text { Social Rep- } \\
\text { resentation } \\
\text { Theory }\end{array}$ & $\begin{array}{l}\text { Nine primigravidae } \\
\text { aged 36-39 }\end{array}$ & $\begin{array}{l}\text { The results show that there is lack } \\
\text { of information on risk prenatal care. } \\
\text { Women are worried about their own } \\
\text { and their children's health, realize there } \\
\text { are changes in the role of women solely } \\
\text { as mothers, and emphasize their career } \\
\text { and studies; therefore, they fear the } \\
\text { changes in their routine. After the age of } \\
35 \text { they feel mature enough to conceive. }\end{array}$ \\
\hline $\begin{array}{l}\text { First mothering } \\
\text { over } 35 \text { years: } \\
\text { questioning the } \\
\text { association of } \\
\text { maternal age and } \\
\text { pregnancy risk }\end{array}$ & $\begin{array}{l}\text { Australia } \\
2007\end{array}$ & $\begin{array}{l}\text { To relate the negotiation } \\
\text { of the risk in primiparas of } \\
\text { advanced maternal age }\end{array}$ & $\begin{array}{l}\text { Qualitative/ } \\
\text { Descriptive }\end{array}$ & $\begin{array}{l}22 \text { primiparas aged } \\
35 \text { and above }\end{array}$ & $\begin{array}{l}\text { Women perceive the risk; however, } \\
\text { they have little information on it. } \\
\text { They deal with the uncertainty of a } \\
\text { healthy pregnancy, negotiate the risk } \\
\text { looking after their own health and } \\
\text { managing their anxiety, and have hope } \\
\text { that the outcome will be positive. }\end{array}$ \\
\hline $\begin{array}{l}\text { Postpartum } \\
\text { experiences of } \\
\text { older Japanese } \\
\text { primiparas during } \\
\text { the first month } \\
\text { after childbirth } \\
\text { (21) }\end{array}$ & $\begin{array}{l}\text { Japan } \\
2014\end{array}$ & $\begin{array}{l}\text { To describe the experiences } \\
\text { during the first month after } \\
\text { childbirth of Japanese } \\
\text { primiparas of advanced age }\end{array}$ & $\begin{array}{l}\text { Qualitative/ } \\
\text { Descriptive }\end{array}$ & $\begin{array}{l}21 \text { primiparas aged } \\
35 \text { and above }\end{array}$ & $\begin{array}{l}\text { Women were worried about their } \\
\text { own and their babies' health, and } \\
\text { felt tired and aware of their age- } \\
\text { related physical limits. They worried } \\
\text { about the changes in their lifestyle } \\
\text { but felt fulfilled by motherhood. }\end{array}$ \\
\hline $\begin{array}{l}\text { Uncertainty } \\
\text { during } \\
\text { perimenopause: } \\
\text { perceptions of } \\
\text { older first-time } \\
\text { mothers }\end{array}$ & $\begin{array}{l}\text { United } \\
\text { States } \\
2012\end{array}$ & $\begin{array}{l}\text { To analyze the perceptions } \\
\text { of older first-time mothers } \\
\text { of their health during the } \\
\text { transition to menopause }\end{array}$ & $\begin{array}{l}\text { Qualitative/ } \\
\text { Phenom- } \\
\text { enological }\end{array}$ & $\begin{array}{l}13 \text { perimenopausal } \\
\text { women who were } \\
\text { first-time mothers } \\
\text { between the ages } \\
\text { of } 45 \text { and } 56\end{array}$ & $\begin{array}{l}\text { Women showed no familiarity } \\
\text { with signs and symptoms, and } \\
\text { experienced a lack of support } \\
\text { by health care professionals and } \\
\text { difficulty in dealing with symptoms } \\
\text { and looking after their babies at the } \\
\text { same time due to constant irritability, } \\
\text { depression, and emotional changes. }\end{array}$ \\
\hline $\begin{array}{l}\text { Advanced } \\
\text { maternal age and } \\
\text { risk perception: } \\
\text { a qualitative } \\
\quad \text { study }^{(23)}\end{array}$ & $\begin{array}{l}\text { Canada } \\
2012\end{array}$ & $\begin{array}{l}\text { To analyze the perception of } \\
\text { risk by pregnant women at } \\
\text { an advanced maternal age }\end{array}$ & $\begin{array}{l}\text { Qualitative/ } \\
\text { Descriptive }\end{array}$ & $\begin{array}{l}15 \text { primigravidae } \\
\text { aged } 35 \text { and above }\end{array}$ & $\begin{array}{l}\text { Many factors influenced women's risk } \\
\text { perception, such as psychological } \\
\text { factors, vision, and communication with } \\
\text { health care professionals, characteristics } \\
\text { of risk and pregnancy stage. }\end{array}$ \\
\hline $\begin{array}{l}\text { Late motherhood: } \\
\text { the experience } \\
\text { of parturition } \\
\text { for first time } \\
\text { mothers aged } \\
\text { over } 35 \text { years } \\
\text { (24) }\end{array}$ & $\begin{array}{l}\text { Australia } \\
2003\end{array}$ & $\begin{array}{c}\text { To investigate the experiences } \\
\text { of first-time mothers } \\
\text { aged } 35 \text { and above }\end{array}$ & $\begin{array}{l}\text { Qualitative/ } \\
\text { Descriptive }\end{array}$ & $\begin{array}{l}21 \text { primiparas aged } \\
35 \text { and above }\end{array}$ & $\begin{array}{l}\text { Women plan their pregnancies, feel } \\
\text { more responsible after motherhood, } \\
\text { and discover their identities as } \\
\text { mothers. However, they show concern } \\
\text { about their work/career, need more } \\
\text { information during prenatal care and } \\
\text { the postpartum, and feel discriminated } \\
\text { against because of their late pregnancy. }\end{array}$ \\
\hline $\begin{array}{l}\text { Advanced } \\
\text { maternal } \\
\text { age: delayed } \\
\text { childbearing } \\
\text { is rarely a } \\
\text { conscious } \\
\text { choice: a } \\
\text { qualitative study } \\
\text { of women's } \\
\text { views and } \\
\text { experiences }^{(25)}\end{array}$ & $\begin{array}{l}\text { United } \\
\text { Kingdom } \\
2012\end{array}$ & $\begin{array}{l}\text { To understand the factors that } \\
\text { influence women's decision } \\
\text { on postponing motherhood } \\
\text { and to investigate their } \\
\text { experiences and perceptions } \\
\text { of associated risks }\end{array}$ & $\begin{array}{l}\text { Qualitative/ } \\
\text { Phenom- } \\
\text { enological }\end{array}$ & $\begin{array}{l}18 \text { women aged } 35 \\
\text { or above divided } \\
\text { into three groups: } \\
\text { six women with no } \\
\text { children who are } \\
\text { not pregnant, six } \\
\text { who are pregnant } \\
\text { with their first } \\
\text { child, and six who } \\
\text { are not pregnant } \\
\text { and attending a } \\
\text { fertilization clinic }\end{array}$ & $\begin{array}{l}\text { Women said that at } 35 \text { they feel ready } \\
\text { to have a child, in addition to stating } \\
\text { the need for a steady relationship, } \\
\text { maturity, and life experience for } \\
\text { that to happen. Their experiences } \\
\text { revealed a lack of information on } \\
\text { the risks associated with age. }\end{array}$ \\
\hline $\begin{array}{l}\text { "Doing it } \\
\text { properly": the } \\
\text { experience of } \\
\text { first mothering } \\
\text { over } 35 \text { years }{ }^{(26)}\end{array}$ & $\begin{array}{l}\text { Australia } \\
2005\end{array}$ & $\begin{array}{l}\text { To understand the experience } \\
\text { of being first-time mothers } \\
\text { above } 35 \text { years of age }\end{array}$ & $\begin{array}{l}\text { Qualitative/ } \\
\text { Descriptive }\end{array}$ & $\begin{array}{l}22 \text { primgravidae } \\
\text { aged } 35 \text { and above }\end{array}$ & $\begin{array}{l}\text { Women plan for pregnancy, talk } \\
\text { about the lack of information shared } \\
\text { by professionals, and worry about } \\
\text { risks associated with age. They have } \\
\text { difficulties adjusting throughout the } \\
\text { postpartum, face them, and finally } \\
\text { discover themselves as mothers. }\end{array}$ \\
\hline $\begin{array}{l}\text { "Renewed" } \\
\text { "Older" } \\
\text { motherhood/ } \\
\text { mothering: } \\
\text { a qualitative } \\
\text { exploration"27) }\end{array}$ & $\begin{array}{l}\text { United } \\
\text { Kingdom } \\
2015\end{array}$ & $\begin{array}{l}\text { To analyze experiences } \\
\text { of multiparas being } \\
\text { "aged" mothers }\end{array}$ & $\begin{array}{l}\text { Qualitative/ } \\
\text { Descriptive }\end{array}$ & $\begin{array}{l}9 \text { multiparas aged } \\
35 \text { and above }\end{array}$ & $\begin{array}{l}\text { The results show the partners' } \\
\text { importance for maternity at an advanced } \\
\text { age, difficulty reconciling the care for } \\
\text { adolescent children and the new baby, } \\
\text { and being subjected to criticism for the } \\
\text { "wrong" age for the new maternity. }\end{array}$ \\
\hline
\end{tabular}

continued... 


\begin{tabular}{|c|c|c|c|c|c|}
\hline Title & $\begin{array}{l}\text { Country/ } \\
\text { Year of } \\
\text { Publication }\end{array}$ & Objective & $\begin{array}{l}\text { Theoretical } \\
\text { Outline/ } \\
\text { Framework }\end{array}$ & Participants & Main Results \\
\hline $\begin{array}{l}\text { Older Japanese } \\
\text { primiparas' } \\
\text { experiences at } \\
\text { the time of their } \\
\text { post-delivery } \\
\text { hospital stay }{ }^{(28)}\end{array}$ & $\begin{array}{l}\text { Japan } \\
2014\end{array}$ & $\begin{array}{l}\text { To understand the experiences } \\
\text { of primiparas of advanced } \\
\text { age during their puerperium }\end{array}$ & $\begin{array}{l}\text { Qualitative/ } \\
\text { Descriptive }\end{array}$ & $\begin{array}{l}22 \text { primiparas, } \\
\text { puerperal women } \\
\text { aged } 35-44\end{array}$ & $\begin{array}{l}\text { The results show concerns } \\
\text { regarding health, care for the } \\
\text { babies and their growth, and the } \\
\text { childbirth experience, in addition to } \\
\text { satisfaction with pregnancy at this } \\
\text { age and work-related concerns. }\end{array}$ \\
\hline $\begin{array}{l}\text { Lao Lai } \mathrm{Zi}- \\
\text { becoming a } \\
\text { mother: cultural } \\
\text { implications with } \\
\text { Parse's theory }{ }^{(29)}\end{array}$ & $\begin{array}{l}\text { Taiwan } \\
2010\end{array}$ & $\begin{array}{c}\text { To analyze the primiparas' } \\
\text { experiences in the first } \\
\text { year after birth }\end{array}$ & $\begin{array}{l}\text { Qualitative/ } \\
\text { Phenom- } \\
\text { enological }\end{array}$ & $\begin{array}{l}10 \text { primiparas aged } \\
35 \text { and above }\end{array}$ & $\begin{array}{l}\text { The study shows women's ambivalent } \\
\text { feelings regarding motherhood such } \\
\text { as pride, emotion, and gratitude } \\
\text { for becoming a mother, together } \\
\text { with concerns for their own health, } \\
\text { obstacles to their physical recovery, } \\
\text { and time spent caring for the baby. }\end{array}$ \\
\hline $\begin{array}{l}\text { A qualitative } \\
\text { study of the } \\
\text { experiences } \\
\text { of Taiwanese } \\
\text { women having } \\
\text { their first baby } \\
\text { after the age } \\
\text { of } 35 \text { years }^{(30)}\end{array}$ & $\begin{array}{l}\text { Taiwan } \\
2007\end{array}$ & $\begin{array}{l}\text { To analyze Taiwanese } \\
\text { women's experience of } \\
\text { being pregnant for the first } \\
\text { time after the age of } 35\end{array}$ & $\begin{array}{l}\text { Qualitative/ } \\
\text { Phenom- } \\
\text { enological }\end{array}$ & $\begin{array}{l}10 \text { primgravidae } \\
\text { aged } 35 \text { or above in } \\
\text { their third trimester } \\
\text { of pregnancy }\end{array}$ & $\begin{array}{l}\text { Women showed both surprise and } \\
\text { concern about their pregnancy } \\
\text { and its results, and embarrassment } \\
\text { for being older pregnant women } \\
\text { and not conforming to society's } \\
\text { standards. Nonetheless, they feel } \\
\text { fulfilled as mothers. They worry } \\
\text { about changes in their lifestyle. }\end{array}$ \\
\hline $\begin{array}{l}\text { Divergent themes } \\
\text { in maternal } \\
\text { experience in } \\
\text { women older } \\
\text { than } 35 \text { years } \\
\text { of age }\end{array}$ & $\begin{array}{l}\text { United } \\
\text { States } \\
1996\end{array}$ & $\begin{array}{l}\text { To analyze the motherhood } \\
\text { experience as described by } \\
\text { first-time mothers older than } \\
35 \text { years of age, comparing } \\
\text { and contrasting it to the } \\
\text { WPL-R theme categories }\end{array}$ & $\begin{array}{l}\text { Quantita- } \\
\text { tive/ } \\
\text { Qualitative }\end{array}$ & $\begin{array}{l}88 \text { primiparas } \\
\text { aged } 35-42\end{array}$ & $\begin{array}{l}\text { Some subjects converged with those } \\
\text { presented by this study's instrument, and } \\
\text { additional subjects that had not been } \\
\text { previously presented: fear of death; lack } \\
\text { of social support/isolation; tiredness/ } \\
\text { need to recover; career/work issues; } \\
\text { and losing control of the situation. }\end{array}$ \\
\hline $\begin{array}{l}\text { A qualitative } \\
\text { study of older } \\
\text { first-time } \\
\text { mothering in } \\
\text { the first year }{ }^{(32)}\end{array}$ & $\begin{array}{l}\text { United } \\
\text { States } \\
2004\end{array}$ & $\begin{array}{l}\text { To understand the experience } \\
\text { of the first year of being } \\
\text { a mother for the first time } \\
\text { at an advanced age }\end{array}$ & $\begin{array}{l}\text { Qualitative/ } \\
\text { Phenom- } \\
\text { enological }\end{array}$ & $\begin{array}{l}\text { Seven primiparas } \\
\text { aged } 36 \text { to } 48\end{array}$ & $\begin{array}{l}\text { Women worry about their babies' } \\
\text { health, say they feel ready for maternity, } \\
\text { and planned pregnancy intensely. } \\
\text { However, they find difficulties in } \\
\text { adjusting to their new life routine. }\end{array}$ \\
\hline $\begin{array}{l}\text { Experience } \\
\text { of pregnancy } \\
\text { beyond } 35 \\
\text { years of age of } \\
\text { women with } \\
\text { low-income }\end{array}$ & $\begin{array}{l}\text { Brazil } \\
2013\end{array}$ & $\begin{array}{l}\text { To understand the social } \\
\text { representations of pregnancy } \\
\text { above the age of } 35 \text { from } \\
\text { low-income women }\end{array}$ & $\begin{array}{l}\text { Qualitative/ } \\
\text { Social Rep- } \\
\text { resentation } \\
\text { Theory }\end{array}$ & $\begin{array}{l}25 \text { pregnant women } \\
\text { aged } 35 \text { or above }\end{array}$ & $\begin{array}{l}\text { Late pregnancy is connected to } \\
\text { the consolidation of new marital } \\
\text { relationships, financial stability, } \\
\text { and maturity of the couple. Women } \\
\text { represent this experience as being } \\
\text { positive when there is previous } \\
\text { planning. Without these conditions, } \\
\text { representations are negative. }\end{array}$ \\
\hline $\begin{array}{l}\text { A study on the } \\
\text { experiences of } \\
\text { late pregnancy }\end{array}$ & $\begin{array}{l}\text { Brazil } \\
2014\end{array}$ & $\begin{array}{l}\text { To describe the experience } \\
\text { of women who get pregnant } \\
\text { above the age of } 35 \text { and } \\
\text { analyze their experience } \\
\text { from the perspective of } \\
\text { gender and vulnerability }\end{array}$ & $\begin{array}{l}\text { Qualitative/ } \\
\text { Descriptive }\end{array}$ & $\begin{array}{l}16 \text { women in the } \\
\text { puerperal cycle } \\
\text { aged } 36-48\end{array}$ & $\begin{array}{l}\text { Women see positive points in } \\
\text { pregnancy above the age of } 35 \\
\text { such as maturity, discernment, } \\
\text { and stability in their relationships } \\
\text { and professional life. The negative } \\
\text { points are tiredness, generational } \\
\text { discrimination, and health problems. }\end{array}$ \\
\hline $\begin{array}{c}\text { Factors } \\
\text { influencing } \\
\text { women's } \\
\text { decisions } \\
\text { about timing of } \\
\text { motherhood }^{(35)}\end{array}$ & $\begin{array}{l}\text { Canada } \\
2006\end{array}$ & $\begin{array}{l}\text { To explore the factors } \\
\text { that influence women's } \\
\text { decisions at the moment } \\
\text { of becoming mothers }\end{array}$ & $\begin{array}{l}\text { Qualitative/ } \\
\text { Descriptive }\end{array}$ & $\begin{array}{l}45 \text { women divided } \\
\text { into age groups }\end{array}$ & $\begin{array}{l}\text { They considered } 35 \text { years and } \\
\text { above to be the ideal age to get } \\
\text { pregnant, and were influenced by } \\
\text { factors like independence, financial } \\
\text { stability, and steady relationships. }\end{array}$ \\
\hline
\end{tabular}

\section{DISCUSSION}

The results point out that the experiences of pregnancy at an advanced age are interwoven with some factors that can influence the healthy development of a pregnancy at a late age and encompass women's physical, social, and psychological issues according to the four theme categories found.

Health care professionals must be a reference for pregnant women, and the information that must be given to them before and during prenatal care is strongly associated with women's good emotional development in pregnancy. Even though doctors are the main reference to them, nurses have a key role in providing guidelines on health care during pregnancy and after childbirth, care for the newborn, and support for these women's subjective needs ${ }^{(12,36-38)}$.

Although the lack of information in perimenopause was mentioned in just one article, this constitutes a new need in health care services to rethink the care provided to older women. Thus, professionals must be prepared to provide 
guidelines about this transition period of a woman's life, especially when connected to pregnancy. The lack of information in this case can be related with its low occurrence, even though the incidence of pregnancies at a late age has been growing lately ${ }^{(39)}$.

Studies suggest that there is an authoritarian relationship between health care professionals and older pregnant women, which interferes with the patient/professional relationship and does not elicit the bond for sharing information and feelings that are considered important by women, which go beyond the concern with age-related physical health ${ }^{(12,36,40)}$.

This authoritarian and disciplinary attitude is also associated with focusing attention and care on the age of mothers, who are seen as accountable for maternal and fetal disorders. Health care prioritizes this aspect and as it concentrates on the risks, it highlights the label of a type of pregnancy that is different from others, i.e., abnormal. This situation can increase pregnant women's feelings of guilt for having postponed pregnancy, making them believe that the responsibility for the baby's health condition is solely their own ${ }^{(36,41)}$.

This strict relationship can also lead women to seek information whose sources are not connected to health care services. This would be a risk, because it can come across fraudulent and untrue information. The fact that women search for information on the Internet and from other sources due to insufficiency of clarifications during prenatal care was one of the findings of this study. There is an evergrowing range of reports on health and illness that is available to anyone. Although this is an advance in communications in the scope of health and illness, this raises a concern for the veracity and exactness of this information ${ }^{(42)}$.

As for the second category, the risks associated with maternal age were described by both Brazilian and international studies ${ }^{(1,7-10,13-14)}$. Even though the results of the previous category evidenced a lack of information, pregnant women realize the risks they are taking during a pregnancy at a late age. Such fact is evidenced by the number of publications found referring to women's concern about the baby's health.

One study ${ }^{(36)}$ described the risk as being perceived differently by health care professionals and pregnant women. The former assessed the risk objectively, based on protocols and scientific evidence that guided their practice, whereas the latter had a subjective notion of risk, assessing it according to their own values and previous experiences.

Risk perception is different from risk itself and reflects the expectation of the probability of an event. Nevertheless, risk perception is not clearly defined yet and is often used as synonymous with concern. The awareness of risk during pregnancy is important because it affects the way women chose to care for their health, their motivations in seeking prenatal care, decisions about the birth location, choices of medical interventions, and adherence to medical procedures and health care recommendations ${ }^{(43)}$. It is important that nurses understand that the perception and notion of risk are different between health care professionals and patients; consequently, the relationship between them and the pregnant women's understanding of their own situation can be improved ${ }^{(36)}$.

One study ${ }^{(43)}$ made a comparison between young and older pregnant women regarding their perception of risk in pregnancy and found that older women have a better perception. This fact can be associated with older pregnant women's life experience and maturity ${ }^{(4)}$ and to the fact that they are better informed about risks since the focus of their care often deals more with biological factors and health problems derived from late pregnancy. They believe that their age makes their pregnancy and babies more vulnerable; therefore they worry about how the outcome of their pregnancy can affect their babies' health ${ }^{(43)}$.

With regard to the ideal moment to conceive, as seen in literature, there are many factors that lead contemporary women to postpone motherhood ${ }^{(45-46)}$. In this study, the results also show that waiting to achieve financial stability influences the time of conception. However, even though career and work-related issues are mentioned as the main reasons for postponing, there are authors ${ }^{(3,47)}$ who show that the primary reason is the choice of the right partner to build a family with.

In studies about the choice of ideal partners for a relationship ${ }^{(48-49)}$, it is seen that women value traits related to the financial stability potential that men will have in the future, i.e., traits that show more resources to be invested in them and their future children. They also value men's ability to protect them physically and their potential to become good fathers. Authors highlight that the cultural influence that pervades marital relations must be taken into account.

Another factor related to the ideal moment to conceive is maturity, which is seen as an advantage in late motherhood. Studies show that older mothers are better prepared and organized to play the role of mothers; thus, they consider it to be the right moment. Women point out that with the experience old age gives them, they feel more emotionally balanced, tolerant, mature, and responsible towards motherhood. With maturity, women feel more competent and secure to look after their children ${ }^{(41,50-51)}$. In contrast, one study ${ }^{(47)}$ found that even older women may feel too immature to conceive. Of the women between 36 and 40 years of age who were studied, the majority showed that they did not want to or did not know whether they wanted to have children, either because they had not found the right partner or because they did not feel mature enough to build a family.

In addition to the advantages mentioned, one longitudinal study ${ }^{(52)}$ showed that not only are there positive aspects for older mothers, but also for their children. This study found better health and development in the first five years of life among children of older women compared with children of younger women. It was clear that children of older women had fewer risks of injuries, better levels of language development, and fewer emotional difficulties in comparison with children of younger women. These data are attributed to the fact that older mothers are more prone to prepare for pregnancy emotionally, physically, psychologically, socially, financially, and in terms of relationships. These are 
indicators that these women often have healthier children and with better development capacities.

However, although maternal age is a positive aspect as far as maturity is concerned in this review, the results also pointed out that women at times feel discriminated against for their age and their pregnancy. Authors ${ }^{(41)}$ called attention to the need for the health care team to do what they can not to focus their care solely on women's age in order not to strengthen the stigma, the prejudice, and the censure around the wrong moment of pregnancy at advanced maternal age. They also highlight that these attitudes can trigger additional risk factors, such as anxiety, thus harming the normal development of this period.

Regarding the adjustment to the new routine, women's performance in multiple roles in society ends up influencing their relationship with motherhood. The concurrence between work and motherhood was mentioned in this review as a concern to women, who feared their progress in their career being hindered or harmed. With pregnancy, there is a tendency to work less, and this could directly affect their performance at work, especially in the case of those women at higher, very demanding positions. Some women decided not to use their maternity leave and ended up feeling guilty for having to leave their children to be looked after by other people. There were also mothers who preferred to give up their job in favor of motherhood, putting their professional career in second place ${ }^{(51)}$.

Women who were 35 years or above and had their first baby at this age could give a new meaning to their existence and faced challenges in their adjustment to their new life. Even though they feel competent playing other roles and often establish routines connected to these functions, older mothers may have difficulties related to the interruption of their routines. In another study, most older women felt ready for motherhood and planned their pregnancy, which was the fulfillment of a long and deep desire to conceive a child. In spite of that, they had difficulty reorganizing their daily activities ${ }^{(12)}$.

The number of studies included in this review was small when compared with the number of studies currently available. This limit can be justified based on the fact that all of the studies dealing with medical issues specifically associated with pregnancy at a late age-which are the vast majority of studies related to this subject-were excluded at the title-and-abstract-reading stage because they did not deal directly with the main focus of this review. Another limit was the exclusion of studies produced in languages that did not belong to the inclusion criteria. To minimize the study limits, searches were conducted with accurate descriptors and key words so that the retrieval of studies could be comprehensive. Studies that were eventually included made up a diverse selection, and the comprehension of the questions posed by them means that the conclusions that can be extracted from the present review are valuable, relevant, and useful.

The studies presented in this research are mostly international and were authored by at least one nurse, pointing to the professional's inclusion in matters that pertained to the subject. Although the phenomenon of having children at an older age is common in developed countries, an analysis of the experiences of older pregnant women in Brazil is still necessary. From this perspective, new research involving this study target population should be conducted to determine a more adequate way to design care that can better cater to the individual needs of older women. Additionally, this can foster reflection on the development of public policies targeted at this population since there are no governmental initiatives in Brazil today that are directed specifically to pregnant women whose age is 35 and above.

The goal of this study is to help build knowledge in the nursing area directed to the care of older pregnant women. The experiences presented contribute resources to (re)think the care and action strategies that are part of the nursing practice and can improve the development of late pregnancy.

\section{CONCLUSION}

This integrative review enabled the authors to conclude that the women who plan to get pregnant at an older age see themselves as being well prepared to conceive, both financially and psychologically. They hope for positive outcomes during pregnancy despite the insecurity caused by the lack of information on pregnancy risks and their unfamiliarity with the signs and symptoms of these risks, and despite the fact they feel little cared for by health care professionals in this period.

Women also say they feel physically and emotionally fragile to face this reality and experience irritability, depression, emotional oscillations, and difficulties dealing with the conflict posed by adolescent children upon the arrival of the new baby. They also highlight that they are judged by society for their choices, and face concerns about their career and lifestyle. Some of them choose not to use maternity leave to protect their career and others postpone or give up their career to prioritize motherhood.

However, they feel pride, emotion, and gratitude for becoming mothers and are fulfilled in this new phase of their lives in spite of the need to reorganize their family and daily activities.

From this perspective, in the field of care, the authors suggest valuing the approach to older pregnant women by making professionals aware of the importance of issues involving these women, in addition to creating specific groups with a multiprofessional team. By learning about the experiences of women who got pregnant at an older age, there is a possibility to understand aspects that go beyond those around risk, and consequently create care strategies aligned with older women's needs to support them, alleviate their concerns, increase their maternal satisfaction with the care received by nurses, provide exchanges with other women in similar situations, and stimulate the acceptance of pregnancy at a delayed age.

This study shows that strengthening governmental initiatives to cater to the needs of women who get pregnant at an advanced age, and using these findings and the findings of other studies that address pregnancy at an advanced age, is necessary to foster the creation of public policies that include specialized care for these women. 
RESUMO

Objetivo: Identificar na literatura como são descritas as experiências das mulheres com idade igual ou superior a 35 anos na gestação. Método: Revisão integrativa realizada nas bases de dados MEDLINE/PubMed, CINAHL, LILACS e SciELO, sem restrição de período. Resultados: Foram selecionados e analisados 18 estudos que tratavam das experiências das mulheres na gestação em idade avançada. Os estudos evidenciaram quatro categorias temáticas: A busca por informações, que mostrou aspectos como deficit de informações fornecidas pelos profissionais da saúde; Percebendo os riscos, que apontou uma preocupação da mulher com a própria saúde e a do filho; Momento ideal para a maternidade, com diferentes motivos para o adiamento; e Adaptação à nova rotina, com a preocupação em relação às mudanças no cotidiano. Conclusão: A partir dos resultados, foi possível compreender que outros fatores, além dos que incluem os riscos, permeiam as experiências da mulher na gestação em idade avançada e induzem à necessidade de envolver tais aspectos no cuidado de enfermagem para construir estratégias abrangentes e condizentes com as necessidades dessas mulheres.

\section{DESCRITORES}

Idade Materna; Gravidez; Cuidados de Enfermagem; Enfermagem Obstétrica; Revisão.

\section{RESUMEN}

Objetivo: Identificar en la literatura cómo se describen las experiencias de las mujeres con edad igual o superior a 35 años en la gestación. Método: Revisión integradora llevada a cabo en las bases de datos MEDLINE/PubMed, CINAHL, LILACS y SciELO, sin restricción de período. Resultados: Fueron seleccionados y analizados 18 estudios que trataban de la experiencias de las mujeres en la gestación en edad avanzada. Los estudios evidenciaron cuatro categorías temáticas: La búsqueda por informaciones, que mostró aspectos como déficit de informaciones proporcionadas por los profesionales sanitarios; Percibiendo los riesgos, que señaló una preocupación de la mujer por la propia salud y la del hijo; Momento ideal para la maternidad, con distintos motivos para el aplazamiento; y Adaptación a la nueva rutina, con la preocupación con respecto a los cambios en el cotidiano. Conclusión: A partir de los resultados, fue posible comprender que otros factores, además de los que incluyen los riesgos, están involucrados en las experiencias de la mujer en la gestación en edad avanzada e inducen a la necesidad de abarcar dichos aspectos en el cuidado de enfermería para construir estrategias amplias y condecentes con las necesidades de esas mujeres.

\section{DESCRIPTORES}

Edad Materna; Embarazo; Atención de Enfermería; Enfermería Obstétrica; Revisión.

\section{REFERENCES}

1. Ojule JD, Ibe VC, Fiebai PO. Pregnancy outcome in elderly primigravidae. Ann Afr Med. 2011;10(3):204-8.

2. Cooke A, Mills TA, Lavender T. 'Informed and uninformed decision making' —Women's reasoning, experiences and perceptions with regard to advanced maternal age and delayed childbearing: meta-synthesis. Int J Nurs Stud. 2010;47(10):1317-29.

3. Welbi E, Chalmers A, Holly Y. Delayed motherhood: understanding the experiences of women older than age 33 who are having abortions but plan to become mothers later. Can Fam Physician [Internet]. 2012 [cited 2015 Aug 8];58(10):e588-95. Available from: http://www. ncbi.nlm.nih.gov/pmc/articles/PMC3470537/

4. Hanson B. Questioning the construction of maternal age as a fertility problem. Health Care Women Int. 2003;24(3):166-76.

5. Brasil. Ministério da Saúde; Secretaria de Atenção à Saúde, Departamento de Ações Programáticas Estratégicas. Gestação de alto risco: manual técnico. Brasília: MS; 2012.

6. Brasil. Ministério da Saúde; Secretaria de Políticas de Saúde, Área Técnica de Saúde da Mulher. Parto, aborto e puerpério: assistência humanizada à mulher. Brasília: MS; 2001.

7. Gravena AAS, Sass A, Marcon SS, Pelloso SM. Outcomes in late-age pregnancies. Rev Esc Enferm USP [Internet] 2012 [cited 2015 July 6];46(1):15-21. Available from: http://www.scielo.br/pdf/reeusp/v46n1/v46n1a02.pdf

8. Betancourt Gamboa K, Ramírez Milán O, Arrieta García R, Guerra Menéndez J, Muñoz Rodríguez MM. Aspectos epidemiológicos asociados a alteraciones del desarrollo em embarazadas añosas. Rev AMC [Internet] 2010 [citado 2015 Ago. 6];14(2). Disponible en: http://scielo.sld.cu/pdf/amc/v14n2/amc150210.pdf

9. Gonçalves ZR, Monteiro DLM. Complicações maternas em gestantes com idade avançada. Femina [Internet] 2012 [citado 8 jul. 2015];40(5):275-9. Disponível em: http://files.bvs.br/upload/S/0100-7254/2012/v40n5/a3418.pdf

10. Santos GHN, Martins MG, Sousa MS, Batalha SJC. Impacto da idade materna sobre os resultados perinatais e via de parto. Rev Bras Ginecol Obstet [Internet]. 2009 [citado 2015 jul. 10];31(7):326-34. Disponível em: http://www.scielo.br/pdf/rbgo/v31n7/v31n7a02.pdf

11. Salem KB, El Mhamdi S, Amor IB, Sriha A, Letaief M, Soltani MS. Caracteristiques epidemiologiques et chronologiques des parturientes aux ages extremes dans la Región de Monastir entre 1994-2003. Tunisie Méd [Internet]. 2010 [cited 2015 July 10];88(8):563-8. Available from: http://www.latunisiemedicale.com/article-medicale-tunisie.php?article=1392

12. Lampinen R, Vehviläinen-Julkunen K, Kankkunen P. A review of pregnancy in women over 35 years of age. Open Nurs J [Internet]. 2009 [cited 2015 July 28];3:33-8. Available from: http://www.ncbi.nlm.nih.gov/pmc/articles/PMC2729989/

13. Sauer MV. Reproduction at an advanced maternal age and maternal health. Fertil Steril. 2015;103(5):1136-43.

14. Liu LC, Wang YC, Yu MH, Su HY. Major risk factors for stillbirth in different trimesters of pregnancy: a systematic review. Taiwan J Obstet Gynecol. 2014;53(2):141-5.

15. Ganong LH. Integrative reviews of nursing research. Res Nurs Health. 1987;10(1):1-11.

16. Mendes KDS, Silveira RCCP, Galvão CM. Revisão integrativa: método de pesquisa para a incorporação de evidências na saúde e na enfermagem. Texto Contexto Enferm [Internet]. 2008 [citado 10 jun. 2015];17(4):758-64. Disponível em: http://www.scielo.br/pdf/tce/ v17n4/18.pdf 
17. Moher D, Liberati A, Tetzlaff J, Altman DG; PRISMA Group. Preferred reporting items for systematic reviews and meta-analyses: the PRISMA statement. PLoS Med [Internet]. 2009 [cited 2015 Sep 4];6(7):e1000097. Available from: http://www.ncbi.nlm.nih.gov/pmc/ articles/PMC2707599/

18. O'Connor A, Doris F, Skirton H. Midwifery care in the UK for older mothers. Br J Midwifery. 2014;22(8):568-77.

19. Teixeira ETN. Adiamento da maternidade: ser mãe depois dos 35 anos [dissertação]. Rio de Janeiro: Fundação Oswaldo Cruz, Escola Nacional de Saúde Pública; 1999.

20. Carolan M, Nelson S. First mothering over 35 years: questioning the association of maternal age and pregnancy risk. Health Care Women Int. 2007;28(6):534-55.

21. Mori E, Iwata H, Sakajo A, Maehara K, Ozawa H, Maekawa T, et al. Postpartum experiences of older Japanese primiparas during the first month after childbirth. Int J Nurs Pract. 2014; 20 Suppl 1:20-31.

22. Morgan P, Merrell J, Rentschler D, Chadderton H. Uncertainty during perimenopause: perceptions of older first-time mothers. J Adv Nurs. 2012;68(10):2299-308.

23. Bayrampour H, Heaman M, Duncan KA, Tough S. Advanced maternal age and risk perception: a qualitative study. BMC Pregnancy Childbirth [Internet]. 2012 [cited 2015 July 5];12:100. Available from: http://www.ncbi.nlm.nih.gov/pmc/articles/PMC3490979/

24. Carolan M. Late motherhood: the experience of parturition for first time mothers aged over 35 years. Aust J Midwifery. 2003;16(2):17-20.

25. Cooke A, Mills TA, Lavender T. Advanced maternal age: delayed childbearing is rarely a conscious choice a qualitative study of women's views and experiences. Int J Nurs Stud. 2012;49(1):30-9.

26. Carolan M. "Doing it properly": the experience of first mothering over 35 years. Health Care Women Int. 2005;26(9):764-87.

27. Jarvie R, Letherby G, Stenhouse E. "Renewed" "Older" motherhood/mothering: a qualitative exploration. J Women Aging [Internet] 2015 [cited 2015 jul 3]; 27(2):1-20.

28. Sakajo A, Mori E, Maehara K, Maekawa T, Ozawa H, Morita A, et al. Older Japanese primiparas' experiences at the time of their postdelivery hospital stay. Int J NursPract. 2014;20 Supl 1:9-19.

29. Yu-O Yang, Chung-Hey Chen, Hui-Lai Chiu. Lao Lai Zi - becoming a mother: cultural implications with Parse's Theory. Nurs Sci Q. 2010;23(3):240-4

30. Yu-O Yang, Peden-McAlpine C, Chung-Hey Chen. A qualitative study of the experiences of Taiwanese women having their first baby after the age of 35 years. Midwifery. 2007;23(4):343-9.

31. Reece SM, Harkless G. Divergent themes in maternal experience in women older than 35 years of age. Appl Nurs Res. 1996;9(3):148-53.

32. Nelson AM. A qualitative study of older first-time mothering in the first year. J Pediatr Health Care. 2004;18(6):284-91.

33. Parada CMGL, Tonete VLP. Experiência da gravidez após os 35 anos de mulheres com baixa renda. Esc Anna Nery Rev Enferm [Internet] 2009 [citado 2015 jul. 10]; 13(2):385-92. Disponível em: http://www.scielo.br/pdf/ean/v13n2/v13n2a21

34. Oliveira LMS. Um estudo sobre a vivência da gravidez tardia [dissertação]. Rio de Janeiro: Universidade do Estado do Rio de Janeiro, Faculdade de Enfermagem; 2014

35. Benzies K, Tough S, Tofflemire K, Frick C, Faber A, Newburn-Cook C. Factors influencing women's decisions about timing of motherhood. J Obstet Gynecol Neonatal Nurs. 2006;35(5):625-33.

36. Carolan MC. Towards understanding the concept of risk for pregnant women: some nursing and midwifery implications. J Clin Nurs. 2009;18(5):652-8.

37. Luciano MP, Silva EF, Cechetto FH. Orientations of nursing in the high risk gestation: the pregnant perceptions. Rev Enferm UFPE Online [Internet] 2011 [cited 2015 aug6];5(5):1261-266. Available from: http://www.revista.ufpe.br/revistaenfermagem/index.php/revista/article/ viewArticle/1727

38. Brooten D, Youngblut JM, Donahue D, Hamilton M, Hannan J, Neff DF. Women with high-risk pregnancies, problems, and APN interventions. J Nurs Scholarsh [Internet]. 2012 [cited 2015 Aug 5];39(4):349-57. Available from: http://www.ncbi.nlm.nih.gov/pmc/ articles/PMC3532049/pdf/nihms211829.pdf

39. Baldwin MK, Jensen JT. Contraception during the perimenopause. Maturitas. 2013;76(3):235-42.

40. Piccinini CA, Carvalho FT, Ourique LR, Lopes RS. Percepções e sentimentos de gestantes sobre o pré-natal. Psic Teor Pesq [Internet]. 2012 [citado 2015 jul. 10];28(1):27-33. Disponível em: http://www.scielo.br/pdf/ptp/v28n1/04.pdf

41. Gomes AG, Donelli TMS, Piccinini CA, Lopes RCS. Maternidade em idade avançada: aspectos teóricos e empíricos. Interação. 2008;12(1):99-106.

42. Garbin HBR, Pereira Neto AF, Guilam MCR. A internet, o paciente expert e a prática médica: uma análise bibliográfica. Interface (Botucatu) [Internet] 2008 [citado 2015 ago. 05];12(26):579-88. Disponível em: http://www.scielo.br/pdf/icse/v12n26/a10.pdf

43. Bayrampour H, Heaman M, Duncan KA, Tough S. Comparison of perception of pregnancy risk of nulliparous women of advanced maternal age and younger age. J Midwifery Womens Health. 2012;57(5):445-53.

44. Aasheim V, Waldenström U, Rasmussen S, Schytt E. Experience of childbirth in first-time mothers of advanced age - a Norwegian population-based study. BMC Pregnancy Childbirth [Internet]. 2013 [cited 2015 Aug 10];13:53. Available from: http://www.biomedcentral. com/1471-2393/13/53

45. Maheshwari A, Porter M, Shetty A, Bhattacharya S. Women's awareness and perceptions of delay in childbearing. Fertil Steril [Internet]. 2008 [cited 2015 Aug 13]; 90(4):1036-42. Available from: http://www.fertstert.org/article/S0015-0282(07)02990-1/pdf

46. Metcalfe A, Vekved M, Tough SC. Educational attainment, perception of work place support and its influence on timing of childbearing for Canadian women: a cross-sectional study. Matern Child Health J. 2014;18(7):1675-82. 
47. Schytt E, Nilsen ABV, Bernhardt E. Still childless at the age of 28 to 40 years: A cross-sectional study of Swedish women's and men's reproductive intentions. Sex Reprod Healthc. 2014;5(1):23-9.

48. Gouveia VV, Gonçalves MP, Gomes AIAB, Freires LA, Coelho JAPM. Construção e validação da escala de atributos desejáveis do(a) parceiro(a) ideal. Aval Psicol. [Internet]. 2014 [citado 2015 ago.14];13(1):105-14. Disponível em: http://pesquisa.bvs.br/brasil/resource/ $\mathrm{pt} / \mathrm{psi}-60917$

49. Gomes AIASB, Gouveia VV, Silva Júnior NA, Coutinho ML, Santos LCO. Escolha do(a) parceiro(a) ideal por heterossexuais: são seus valores e traços de personalidade uma explicação? Psic Reflex Crít [Internet]. 2013 [citado 14 ago 2015];26(1):29-37. Disponível em: http://www. scielo.br/pdf/prc/v26n1/04.pdf

50. Oliveira RB, Galdino DP, Cunha CV, Paulino EFR. Gravidez após os 35 anos: uma visão de mulheres que viveram essa experiência. Corpus Sci [Internet]. 2011 [citado 14 ago 2015]; 7(2):99-112. Disponível em: http://apl.unisuam.edu.br/revistas/index.php/corpusetscientia/ article/view/134/103

51. Rybinska A. Motherhood after the age of 35 in Poland. Studia Demogr [Internet]. 2014 [cited 2015 Sep 4];1(165):7-28. Available from: http://www.ncbi.nlm.nih.gov/pmc/articles/PMC4311263/pdf/nihms639377.pdf

52. Sutcliffe AG, Barnes J, Belsky J, Gardiner J, Melhuish E. The health and development of children born to older mothers in the United Kingdom: observational study using longitudinal cohort data. BM] [Internet]. 2012 [cited 2015 Aug 12];345:e5116. Available from: http:// www.ncbi.nlm.nih.gov/pmc/articles/PMC3424227/ 